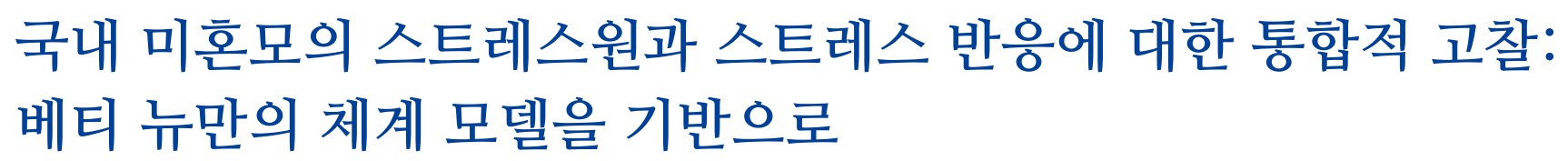

\author{
김성재 ${ }^{1}$, 방경숙 $^{1}$, 이금희 ${ }^{2}$, 임지희 ${ }^{2}$, 정예슬 $^{2}$, 송민경 ${ }^{3}$ \\ ${ }^{1}$ 서울대학교 간호대학 · 간호과학연구소 교수, ${ }^{2}$ 서울대학교 간호대학 대학원생, ${ }^{3}$ 울산대학교 간호학과 교수
}

\title{
Stressors and Stress Responses of Unmarried Mothers Based on Betty Neuman's Systems Model: An Integrative Review
}

\author{
Sungjae Kim ${ }^{1}$, Kyung-Sook Bang ${ }^{1}$, Gumhee Lee ${ }^{2}$, Jihee Lim², Yeseul Jeong ${ }^{2}$, Min Kyung Song ${ }^{3}$ \\ ${ }^{1}$ Professor, College of Nursing · The Research Institute of Nursing Science, Seoul National University, Seoul; ${ }^{2}$ Graduate Student, College of Nursing, Seoul National \\ University, Seoul; ${ }^{3}$ Professor, Department of Nursing, Ulsan University, Ulsan, Korea
}

\begin{abstract}
Purpose: The purpose of this study was to explore the structure of variables in studies related to unmarried mothers (UMs) based on Neuman's systems model, and the stressors and stress responses of UMs. Methods: Whittemore and Knafl's methodology for integrative reviews was applied. The literature was searched using five electronic databases (KISS, KMbase, KoreaMed, NDSL, and RISS) and a total of 99 variables were collected from 15 studies published between 2009 and 2019. Results: The main stressors for UMs were a sense of loss and burden caused by childbirth and childrearing. The main stress responses were parenting stress and depression, respectively. Within the basic structure of variables related to UMs, self-esteem played a crucial role by helping UMs adapt to their situation. Meanwhile, social support of UMs was significantly correlated with parenting stress, depression, and self-esteem. Conclusion: In order to understand UMs' stress, is necessary to explore their sense of loss, burden, and self-esteem. Furthermore, it is important to assess the level of parenting stress and depression of UMs and to provide effective interventions to alleviate these stressors. The results of this study provide useful knowledge that can be applied to nursing assessment and interventions for stress management in UMs.
\end{abstract}

Key words: Mothers; Stress, psychological; Self concept; Depression

\section{Corresponding author Gumhee Lee \\ https://orcid.org/0000-0003-3152-5064}

College of Nursing, Seoul National University,

103 Daehak-ro, Jongno-gu, Seoul 03080, Korea

TEL +82-2-740-8488 FAX +82-2-765-4103

E-MAIL Ighpw@snu.ac.kr

*이 성과는 정부(과학기술정보통신부)의 재원으로 한국연구재단의 지원을 받아 수행된 연구임(No. NRF-2019R1A2B5B010705192).

*This work was supported by the National Research Foundation of Korea (NRF) grant funded by the Korea government (MSIT)

(No. NRF-2019R1A2B5B010705192).

Key words 어머니, 스트레스, 자아개념, 우울

Received Mar 2, 2020 Revised Mar 30, 2020 Accepted Apr 7, 2020

(.) This is an Open Access article distributed under the terms of the Creative Commons Attribution NonCommercial License (http://creativecommons.org/licenses/by-nc/4.0/) which permits unrestricted noncommercial use, distribution, and reproduction in any medium, provided the original work is properly cited.

\section{서 론}

\section{1. 연구의 필요성}

미혼모는 합법적이고 정당한 혼인관계에 의하지 않고 자녀를 출산할 예정이거나 출산한 여성을 칭하는 일반적인 용어이다[1]. 미혼모를 18 세 이하 자녀를 양육하고 있는, 법적으로 미혼인 친모 로 규정하고 있는 통계청의 보고에 의하면, 2018년의 국내 미혼모 수는 총 21,254명이다[2]. 미혼모 수의 추이에 대한 공식 통계 자료 는 없으나 전체 출생아에서 혼인 외 출생아가 차지하는 구성비를 통해 이를 대략적으로 가늠해 볼 수 있다. 2008년 혼인 외 출생아 구성비가 $1.8 \%(8,400$ 명)에서 2013년에 2.1\%(9,300명), 2018년에 
는 $2.2 \%(7,200$ 명 $)$ 로 점차 증가하고 있음을 볼 때[3], 그에 따라 미 혼모 비율이 증가하고 있다고 추측할 수 있다.

미혼모는 법적 혼인관계에서 출산과 양육을 하는 어머니와는 출산과 양육측면뿐 아니라 사회적응 측면에서도 매우 다른 경험을 하게 된다[4-6]. 이들은 법적 혼인관계에서의 출산을 중시하는 사 회적 분위기로 인한 낙인을 우려하여 임신과 출산 사실을 외부에 노출하지 않는 특성을 보인다[7]. 이로 인해 산전 관리에 소홀하게 되어 신체적 건강이 위협받기 쉬우며[8], 후회나 죄책감과 더불어 삶에 대한 막연한 불안, 우울, 외로움과 같은 부정적 정서를 경험할 뿐 아니라[4], 가족이나 친구 및 사회의 비판적 시선을 경험하기도 한다[4]. 또한 학업이나 직장을 중단하고 양육을 책임져야 하는 역 할의 변화와 더불어 경제적 어려움도 감당해야 한다[5,6]. 이처럼 미혼모는 신체적, 심리적, 사회적, 경제적으로 불안정한 상황의 특 수성으로 인해 스트레스를 경험하며, 이는 미혼모 자신의 건강은 물론 자녀 양육에도 부정적인 영향을 미친다[5]. 그러므로 자녀의 건강한 성장과 발달을 위해서도 이들을 돕기 위한 돌봄과 지원은 필요하고 중요한 일이다.

미혼모에게 필수적으로 요구되는 도움을 파악하여 이를 효율적 으로 제공하기 위해서는 우선적으로 이들이 경험하는 스트레스원 과 이에 대한 스트레스 반응을 체계적이고 종합적으로 이해할 필 요가 있다. 이제까지 수행된 미혼모의 스트레스에 대한 국내외의 연구는 미혼모의 경험을 질적으로 탐색한 연구 $[4,6,9]$ 이거나, 미혼 모의 양육 스트레스에 영향을 미치는 요인을 단편적으로 조사한 연구 $[5,10,11]$ 이기에 미혼모가 경험하는 스트레스원과 스트레스 반응을 체계적이고 종합적으로 이해하기에는 한계가 있다.

이처럼 복합적인 스트레스원에 다양한 반응을 보이는 대상자를 이해하는 데에 적용할 수 있는 이론으로 Betty Neuman의 체계모 형(Neuman's Systems Model, NSM)이 있다. NSM은 대상자를 환경과 역동적으로 상호작용하는 총체적인 체계로 보고 대상자 체 계라고 명명하였다[12]. 대상자 체계는 5가지 변수(생리적, 심리 적, 사회문화적, 발달적, 영적 변수)로 구성되어 있으며, 인간을 둘 러싼 환경은 내부 환경, 외부 환경, 창조된 환경으로 구분된다[12]. Newman은 대상자 체계의 건강 수준과 환경의 특성에 따라서 대 상자 체계가 보이는 스트레스 반응은 차이가 있기 때문에 이를 고 려한 체계적이고 종합적인 사정이 중요하다고 강조하였다[13]. 이 러한 NSM의 대상자 체계 개념을 미혼모에 적용한다면 신체건강 문제는 생리적 변수로, 우울은 심리적 변수로, 경제적 어려움은 사 회문화적 변수로, 모성역할전환은 발달적 변수로, 그리고 죄책감 은 영적 변수로 구분하여 사정할 수 있을 것이다.

더불어 NSM에서는 대상자 체계의 구조를 기본적 생존요인(기 본구조)과 이를 동심으로 둘러싸고 있는 가상의 구조인 3 개의 방어
선(유연방어선, 정상방어선, 저항선)으로 도식화하였다[12]. 또한 대상자 체계를 침범하는 스트레스원을 3 가지 유형으로 구분하였 으며, 스트레스 반응을 스트레스원에 대항하기 위해 이 3 개의 방어 선이 단계별로 활성화되는 과정에서 나타나는 불안정성으로 설명 하였다. 즉, 스트레스원에 의해 대상자 체계의 유연방어선과 정상 방어선이 차례로 무너지게 되면, 3 번째 방어선인 저항선이 대상자 체계의 핵심인 기본구조를 보호하기 위해 활성화되어 기능한다. 각 방어선은 활성화되었을 때 나타나는 스트레스 반응에 의해 구 별될 수 있는데, NSM에서는 이 3단계에서 나타나는 스트레스 반 응을 통해 대상자 체계의 기능 수준(건강)을 파악한다. 또한 이 단 계에 따른 기능을 강화시키려는 도움을 1 차, 2 차, 3 차 예방적 간호 중재로 개념화하고 있다[12].

그러므로 NSM를 미혼모의 스트레스 이해에 적용한다면, 미혼 모 대상자 체계를 구성하는 변수와 3 개의 방어선에 대한 확인뿐만 아니라, 이들이 지각하는 스트레스원을 총체적으로 파악하는 데 에 유용한 이론적 틀이 될 수 있다. NSM에서 설명하는 간호중재의 목적은 각 단계에서 대상자 체계가 최적으로 기능하는 데에 영향 을 미치거나 영향을 미칠 수 있는 스트레스원과 역 조건을 줄이는 것이다[12]. 그러므로 NSM의 이론적 틀에 따라 미혼모의 스트레 스원과 단계별 스트레스 반응과의 관계를 확인한다면, 이는 미혼 모의 기능 수준을 사정하고 이에 적합한 예방적 간호중재를 고안 하는 데에 활용할 수 있는 기초자료가 될 것이다.

$\mathrm{NSM}$ 이 스트레스에 초점을 둔 예방적 간호를 강조하고 있음에 도 불구하고, 간호 대상자의 스트레스 탐구에 NSM을 적용한 국내 연구는 찾아보기 어렵다. 국외연구로는 NSM의 주요 개념에 초점 을 두고 통합적 고찰을 수행하여 돌봄제공자의 스트레스원을 파악 한 연구[14]가 있으며, NSM을 활용하여 위험한 성관계를 하는 여 성을 총체적으로 사정한 연구[15]가 있어, 이를 통해 NSM을 적용 한 연구가 간호 지식체 구축에 기여함을 확인할 수 있다.

이에 본 연구에서는 NSM을 이론적 기반으로 하여 미혼모를 대 상으로 수행된 선행 연구를 스트레스원과 스트레스 반응에 초점을 두고 통합적으로 고찰하고자 한다. 이를 통해 일차적으로NSM를 구성하는 추상적인 개념을 미혼모가 경험하는 스트레스원과 스트 레스 반응에 속하는 구체적인 개념 / 변수(으)로 파악하고자 한다. 또한 NSM에서 제시한 스트레스원과 3개 방어선의 관계 구조에 따라서 이에 상응하는 구체적인 개념 /변수의 관계를 구조화하고 자 한다. 특히 구조화 단계에서는 선행 연구에서 유의성이 보고된 변수 간의 관계만을 반영함으로써 과학적 근거를 토대로 국내 미 혼모의 스트레스를 설명하고자 한다. 이를 통해 체계화된 지식은 미혼모가 지닌 간호 요구를 종합적으로 사정하고, 미혼모의 스트 레스 반응을 일련의 단계에 따라 예측할 수 있도록 안내할 뿐 아니 
라, 미혼모의 건강 수준에 따른 $1,2,3$ 차 예방적 간호중재 방안을 고 안하는 데에 기초자료로 활용될 수 있을 것이다.

\section{2. 연구 목적}

본 연구에서는 NSM를 구성하는 주요 개념에 근거하여 미혼모 를 대상으로 한 국내연구를 통합적으로 고찰하고자 한다. 본 연구 의 구체적 목적은 다음과 같다.

- 미혼모를 대상으로 수행된 조사연구에서 선정한 변수를 확인 한다.

- 미혼모의 스트레스원에 해당하는 변수를 파악하고, 이를 인 간 내적, 대인관계적, 인간 외적 스트레스원으로 구분한다.

- 미혼모의 대상자 체계의 구조(3개의 방어선과 기본구조), 스 트레스 반응 및 복구와 5가지 하위체계(생리적, 심리적, 사회 문화적, 발달적, 영적 변수)에 해당하는 변수로 구분한다.

- 주요 변수 간의 상관계수 효과크기를 파악한다.

- NSM의 스트레스원과 스트레스 반응의 관계 구조에 맞추어 서 미혼모의 스트레스원과 3 개의 방어선에 따른 스트레스 반 응의 관계를 구조화한다.

\section{3. 개념적 기틀}

본 통합적 고찰을 안내하는 개념적 기틀은 Newman과Fawcett [12]의 NSM 주요 개념을 근간으로 구성하였다(Figure 1-A). NSM 에서는 환경이 건강에 미치는 영향을 중요시하며, 대상자를 총체 적 접근이 필요한 완전한 체계로 본다. 그러므로 뉴만은 대상자의 간호를 위해서는 종합적인 사정과 전체적인 접근이 필요하고, 스 트레스원과 스트레스 반응 및 자원이 중요하다고 강조하였다.

\section{1) 환경}

환경은 내부 환경(internal environment), 외부 환경(external environment), 그리고 창조된 환경(created environment)으로 구분 된다. 내부 환경은 대상자 내에서 발생하는 모든 힘이나 상호작용 으로 구성된 환경이며, 외부 환경은 대인관계를 포함한 대상자의 외부환경을 의미하며, 창조된 환경은 대상자의 무의식에서 만들 어진 환경을 말한다.

\section{2) 스트레스원}

스트레스원은 인간 내적(intra personal), 대인관계적(inter personal), 인간 외적(extra personal) 스트레스원으로 구분된다. 미 혼모의 연령이나 낮은 교육 수준은 인간 내적 스트레스원에 해당
되는 구체적 변수이다.

\section{3) 대상자/ 대상자 체계}

대상자는 하나의 체계로서 생리적, 심리적, 사회문화적, 발달적, 영적 변수의 5 가지 하위체계로 구분된다. 또한 핵심 체계인 기본구 조가 있고 이를 3개의 방어선으로 둘러싼 구조로 도식화되어 있다. 이 각 구조들도 모두 5개의 하위체계로 이루어져 있다. 예를 들어 미혼모의 피로 수준은 생리적 체계에 해당하는 변수이면서 동시에 유연/정상 방어선에 속하는 변수라고 본다.

\section{4) 대상자/ 대상자 체계의 구조}

인간이 스트레스원에 대응하는 과정은 대상자 체계를 보호하 는 3개 방어선을 통한 3단계로 설명된다(Figure 1).

- 유연방어선: 스트레스원에 대항하는 1 차 방어선으로 완충작 용을 한다. 건강한 생활방식과 효과적인 대처기전은 유연방 어선을 확장한다.

- 정상방어선: 개인의 적응양식이나 생활양식 및 발달단계 등 과 같은 대상자 체계의 변수와 행동을 포함하는데, 이 정상방 어선이 확장되는 것은 건강상태가 좋아짐을 의미한다. 정상 방어선을 통해 대상자 체계가 보호되지 못할 경우에는 다음 방어선인 저항선을 활성화하여 대상자의 핵심 체계인 기본구 조를 보호하고 복구를 지원한다.

- 저항선: 기본구조를 둘러싸고 있으면서 기본구조의 통합성을 유지 보호한다. 스트레스원에 저항하는 동시에 최적의 건강 상태로 복구되도록 내부 및 외부자원을 가동하여 안정을 유 지한다.

- 기본구조: 대상자가 가지는 핵심인 생존요인을 말하며 체계 의 가장 중심에 위치한다. 이는 대상자가 가지고 있는 에너지 자원으로 선천적이거나 유전적 특징, 반응패턴, 대상자 체계 의 강점과 약점, 자아구조 등을 말한다. 미혼모의 자아존중감 은 기본구조에 속한다.

\section{5) 스트레스 반응}

스트레스원이 대상자 체계에 침범했을 때 발생하는 불안정성을 의미한다.

\section{6) 복구}

스트레스에 대한 반응을 처리한 후 일어나는 것으로 일종의 재생 이며, 체계가 안정된 상태로 되돌아가는 것을 의미한다. 미혼모의 부모역할만족은 복구에 해당되는 변수로 본다. 


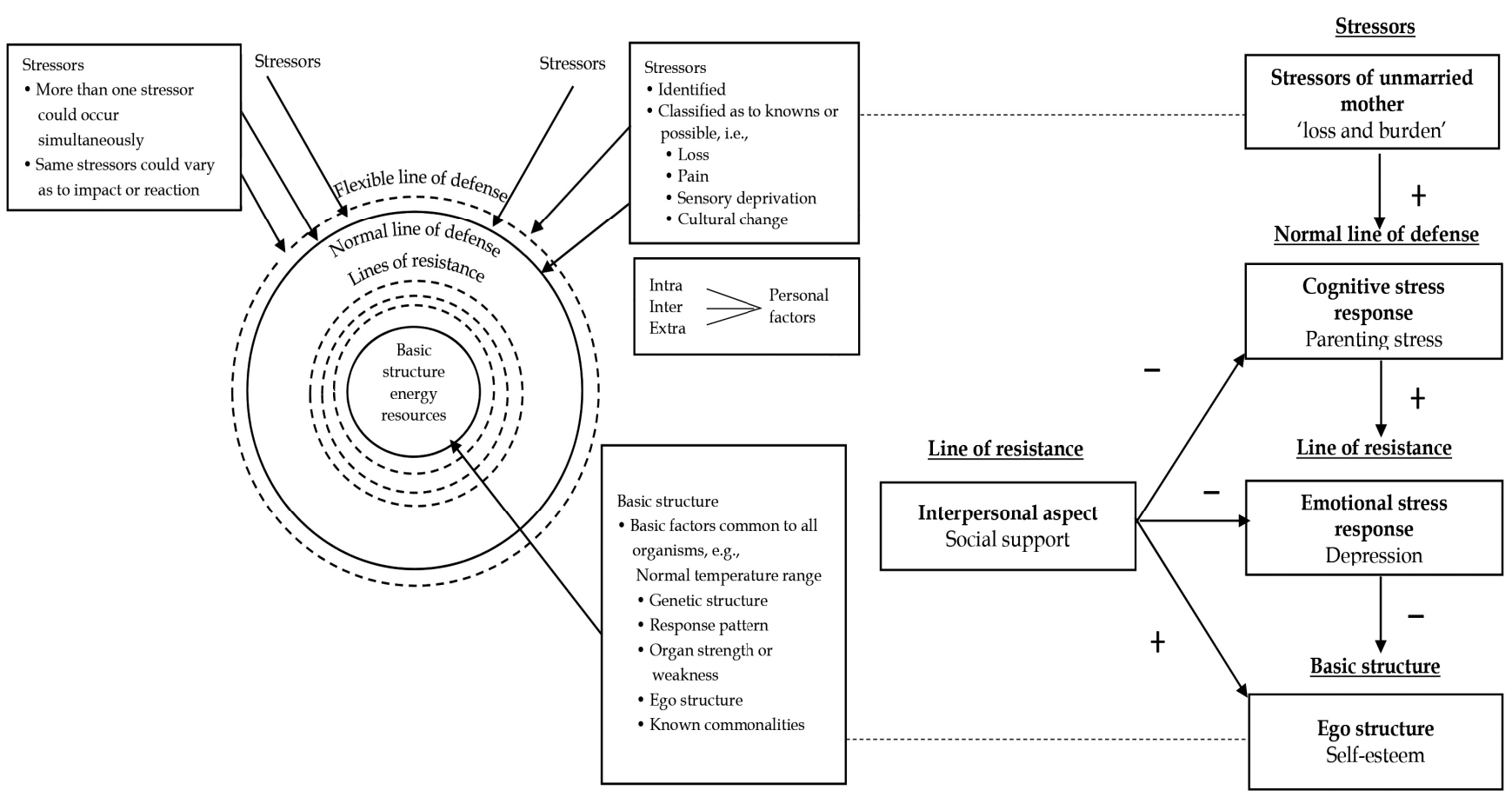

Figure 1-A. Neuman's systems model (Neuman, 2011).

\section{연구 방법}

\section{2. 연구 대상}

\section{1. 연구 설계}

본 연구는 Whittemore와 Knafl [16]의 통합적 고찰 방법을 사 용하여, 국내에 거주하는 미혼모를 대상으로 수행한 조사연구를 $\mathrm{NSM}$ 에 따라 분석한 고찰연구이다. 미혼모 대상자 체계의 변수, 스트레스원과 주요 변수 간의 관계 분석은 다음 5 단계로 이루어졌 다. 1 단계 문제인식 단계에서는 국내거주 미혼모의 스트레스원과 스트레스 반응을 파악하고자 하는 본 연구의 목적을 명확히 하였 다. 2단계 문헌검색 단계에서는 연구 목적에 따라 검색어를 선정하 였으며, 검색 엔진을 이용하여 관련 문헌을 수집하였다. 3 단계 문 헌선정 단계에서는 연구의 목적과 일치하는 문헌을 최종적으로 선 정하였다. 4 단계 자료 분석 단계에서는 수집된 자료를 분석하였으 며, 분석은 1 차 변수확인, 2 차 스트레스원 파악, 3 차 NSM의 개념 에 따른 변수의 분류, 4 차 효과크기 산출, 5 차 변수 간의 관계 구조 화 순으로 이루어졌다. 5 단계 의미해석 단계에서는 스트레스원에 대한 함의와 메타분석 및 문헌고찰 결과로 도출된 변수 간의 관계 의 의미를 해석하여 제시하였다.
Figure 1-B. Structure of the relationships among stress-related variables in unmarried mothers.
연구 문제는 '미혼모 대상의 연구에서 파악한 미혼모의 스트레 스원과 스트레스 반응은 어떠한가?'이다. 선정기준에서 1) 연구 대 상은 국내의 사회문화적 특성이 반영된 연구 결과를 도출하기 위 하여 국내거주 미혼모로 한정하였으며, 법적으로 혼인하지 않은 상태에서 자녀를 출산한 미혼모로서 양육 여부와 거주 형태에 제 한을 두지 않았다. 2) 본 연구에서 파악하고자 하는 스트레스원과 그 반응은 대상과 상황에 따라 다양하기에 문헌수집의 민감도를 높이는 동시에 종합적으로 변수를 파악하기 위해 결과변수인 종속 변수에 제한을 두지 않았다. 3) 연구 설계는 서술적 횡단적 조사연 구와 전향적 코호트 연구로, 근거 수준이 높은 결과를 도출하고자 신뢰도와 타당도가 확보된 객관적 측정도구를 사용한 연구만을 대 상으로 하였다. 배제기준은 초록만 게재한 연구, 고찰연구, 실험연 구, 사례연구, 증례보고, 질적연구이다. 질적연구의 결과로 도출된 주제는 복합적 의미를 내포하고 있어서 본 연구의 목적에 맞도록 특정 변수로 분류하기에는 무리가 있다고 판단하여 배제하였다. 또한 실험연구는 변수 간의 상관관계를 제시하지 않기에 본 연구 의 목적에 적합하지 않다고 판단하여 제외하였다. 


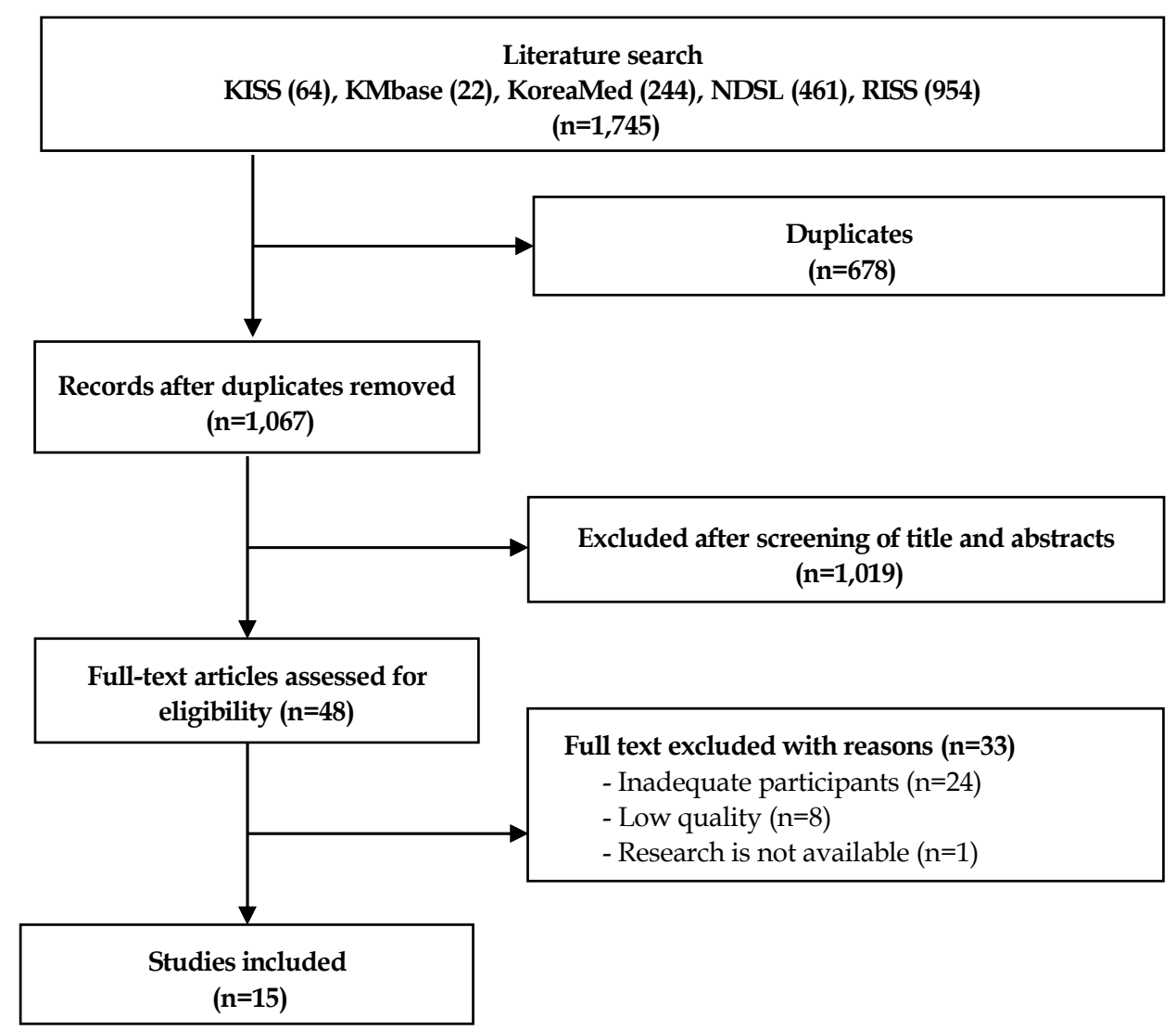

Figure 2. Preferred Reporting Items for Systematic Reviews and Meta-Analyses (PRISMA) flow diagram of the screening process.

\section{3. 자료 수집 방법}

KISS, KMbase, KoreaMed, NDSL, RISS의 5개 검색 엔진을 이 용하여 2인의 연구자가 문헌검색을 시행하였다. 한국어와 영어로 출판된 문헌 중에서 최근의 사회문화적 변화를 반영하기 위하여 출 판 기간을 10 년 이내로 제한하였다. 논문검색에 사용한 주요 키워 드는 '미혼모', '미혼 임부', '미혼 양육모', '청소년 임신', '청소년 한 부모', '10대 임신', 'illegitima*', 'unmarried', 'unwed', 'single', 'teenage', 'young', 'adolescent', 'teen', 'juvenile', 'preteen', 'mother(s)', 'parent(s)', 'pregnancy(ies)', 'mom(s)'을 'AND' 와 'OR'로 조합하여 사용하였다. 각 검색 엔진 별로 KISS 64편, KMbase 22편, KoreaMed 244편, NDSL 461편, RISS 954편으로 총 1,745 편이 검색되었다. 이 중 중복된 문헌 678 편을 제외하고 남 은 1,067 편을 대상으로 제목과 초록을 확인하여 선정기준에 부합 하지 않는 1,019 편의 문헌을 제외하였다. 남은 48 편의 문헌은 전문 을 확보하여 검토하였으며, 이 중 연구 대상이 불분명하거나 출산 한 미혼모가 아닌 문헌 24편, 도구의 신뢰도를 제시하지 않았거나 임의제작한 도구를 사용한 문헌 8편, 원문을 찾을 수 없는 문헌 1편
을 제외하고 최종 15 편이 선정되었다(Figure 2). 이 중 1 편은 연구 대상자 73 명 중 혼인신고자 4 명이 포함되었으나 차지하는 비율이 낮아(약 5.5\%) 선정논문에 포함하였다(Table 1).

\section{4. 문헌의 질 평가}

문헌의 질 평가는 미국국립보건원에서 개발한 질평가 도구 (Study Quality Assessment Tools, SQAT)중 관찰 코호트 및 횡 단적 조사연구의 질평가 도구(Quality Assessment Tool for Observational Cohort and Cross-Sectional Studies) [17]를 이용하 였다. 본 연구에서는 총 13 항목 중에서 조사연구 질평가에 해당하 는 8 개 항목만을 활용하였다. 8개 항목의 내용에는 1) 연구 목적의 제시, 2) 연구 대상의 명확한 정의, 3) $50 \%$ 이상의 참여율, 4) 대상 자선정 및 제외기준의 일관된 적용, 5) 표본수산출에 대한 근거 제 시, 6) 독립변수에서 신뢰도와 타당도가 검정된 도구의 사용, 7) 종 속변수에서 신뢰도와 타당도가 검정된 도구의 사용, 8) 교란변수의 통계적 조정이 포함된다. 각 항목의 기준을 충족시킨 경우 1점을 부 과하여 채점하였다. 문헌의 질 평가는 연구자 4 인이 두 팀으로 나누 
Table 1. Analysis of the Selected Studies

\begin{tabular}{|c|c|c|c|c|c|c|c|c|}
\hline $\begin{array}{l}\text { Authors } \\
\text { (year) }\end{array}$ & $\begin{array}{l}\text { Study design, } N \text {, } \\
\text { major field, } \\
\text { publicity (year } \\
\text { age of children } \\
\text { and mothers) }\end{array}$ & Stressors & $\begin{array}{l}\text { Flexible line of } \\
\text { defense/normal } \\
\text { line of defense }\end{array}$ & Line of resistance & Basic structure & Stress responses & Reconstitution & $\begin{array}{c}\text { Quality of } \\
\text { selected } \\
\text { studies }\end{array}$ \\
\hline $\begin{array}{l}\text { Chang } \\
\text { (2018) }\end{array}$ & $\begin{array}{l}\text { Cross, } 133 \text {, social } \\
\text { work, thesis } \\
\text { (unclear, teens to } \\
40 \text { s) }\end{array}$ & $\begin{array}{l}\text { 1) Age of child } \\
\text { 2) Income } \\
\text { 3) Education level }\end{array}$ & $\begin{array}{l}\text { 4) Health } \\
\text { condition }\end{array}$ & $\begin{array}{l}\text { 5) Social support } \\
\text { (SNG) }\end{array}$ & $\begin{array}{l}\text { 6) Self-esteem } \\
\text { (RSES) }\end{array}$ & $\begin{array}{l}\text { 7) Parenting } \\
\text { stress } \\
\text { (K-PSI-SF) }\end{array}$ & $\begin{array}{l}\text { 8) Job search } \\
\text { efficacy (Jobs II } \\
\text { Survey) }\end{array}$ & 7 \\
\hline $\begin{array}{l}\text { Kim \& } \\
\text { Lee } \\
(2018)\end{array}$ & $\begin{array}{l}\text { Cross, } 131 \text {, social } \\
\text { work, journal } \\
(0 \sim 3,13 \sim 19)\end{array}$ & $\begin{array}{l}\text { 1) Social prejudice } \\
\text { (SPS) }\end{array}$ & $\begin{array}{l}\text { 2) Parenting } \\
\text { behavior (PBS) }\end{array}$ & $\begin{array}{l}\text { 3) Resilience } \\
\text { (RBS) }\end{array}$ & - & - & - & 7 \\
\hline $\begin{array}{l}\text { Oh } \\
\qquad(2018)\end{array}$ & $\begin{array}{l}\text { Cross, } 211 \text {, social } \\
\text { work, thesis } \\
\text { (under } 12 \text {, teens } \\
\text { to over } 30 \text { ) }\end{array}$ & - & $\begin{array}{l}\text { 1) Self-efficacy } \\
\text { (SES) }\end{array}$ & $\begin{array}{l}\text { 2) Social support } \\
\text { (SSS) }\end{array}$ & $\begin{array}{l}\text { 3) Self-esteem } \\
\text { (RSES) }\end{array}$ & - & $\begin{array}{l}\text { 4) Self-sufficiency } \\
\text { outcome (SSO) }\end{array}$ & 7 \\
\hline $\begin{array}{l}\text { Oh \& } \\
\text { Kim. } \\
\text { (2018) }\end{array}$ & $\begin{array}{l}\text { Cross, } 108 \text {, } \\
\text { nursing, journal } \\
(0 \sim 6 \text {, teens to } \\
\text { over } 30)\end{array}$ & $\begin{array}{l}\text { 1) Age of child } \\
\text { 2) Health problem } \\
\text { of child } \\
\text { 3) Job } \\
\text { 4) Education level }\end{array}$ & $\begin{array}{l}\text { 5) Health } \\
\text { perception } \\
\text { (HPQ) }\end{array}$ & $\begin{array}{l}\text { 6) Social support } \\
\text { (SSS) }\end{array}$ & - & $\begin{array}{l}\text { 7) Parenting } \\
\text { stress } \\
\text { (K-PSI-SF) } \\
\text { 8) Depression } \\
\text { (BDI-II) }\end{array}$ & - & 8 \\
\hline $\begin{array}{l}\text { Kim } \\
\text { (2017) }\end{array}$ & $\begin{array}{l}\text { Cross, 252, social } \\
\text { work, thesis } \\
(0 \sim 12,15 \sim 44)\end{array}$ & $\begin{array}{l}\text { 1) Stress during } \\
\text { pregnancy } \\
\text { (DSP) } \\
\text { 2) Age of first } \\
\text { giving birth } \\
\text { 3) Age of child } \\
\text { 4) Job } \\
\text { 5) Grant support } \\
\text { status }\end{array}$ & $\begin{array}{l}\text { 6) Parenting sense } \\
\text { of competence } \\
\text { (PSOC) }\end{array}$ & $\begin{array}{l}\text { 7) Social support } \\
\text { (MSPSS) } \\
\text { 8) Support from } \\
\text { baby's father }\end{array}$ & $\begin{array}{l}\text { 9) Adult } \\
\text { attachment } \\
\text { (AAS) } \\
\text { 10) Maternal } \\
\text { attachment }\end{array}$ & $\begin{array}{l}\text { 11) Parenting } \\
\text { stress (PSI-SF) } \\
\text { 12) Depression } \\
\text { (CESD-10) }\end{array}$ & - & 7 \\
\hline $\begin{array}{l}\text { Park \& } \\
\text { Lee } \\
(2017)\end{array}$ & $\begin{array}{l}\text { Cross, 94, } \\
\text { psychology, } \\
\text { journal (unclear, } \\
\text { unclear) }\end{array}$ & $\begin{array}{l}\text { 1) Health problem } \\
\text { of mother } \\
\text { 2) Job }\end{array}$ & $\begin{array}{l}\text { 3) Stress (stress } \\
\text { scale) } \\
\text { 4) Parenting } \\
\text { motivation } \\
\text { (PMS), } \\
\text { 5) Health } \\
\text { condition }\end{array}$ & $\begin{array}{l}\text { 6) Character } \\
\text { strength (CST) } \\
\text { 7) Support of } \\
\text { parent } \\
\text { 8) Support of } \\
\text { baby's father } \\
\text { 9) Social support } \\
\text { (SSS) }\end{array}$ & $\begin{array}{l}\text { 10) } 5 \text { factors of } \\
\text { personality } \\
\text { psychopathol } \\
\text { ogy (PSY-5 in } \\
\text { MMPI-II) }\end{array}$ & $\begin{array}{l}\text { 11) Perception of } \\
\text { stigma (PSS) }\end{array}$ & $\begin{array}{l}\text { 12) Quality of life } \\
\text { (WHOQOL- } \\
\text { BREF) } \\
\text { 13) Parent role } \\
\text { satisfaction } \\
\text { (PRSS) }\end{array}$ & 7 \\
\hline $\begin{array}{l}\text { Jung } \\
\text { (2016) }\end{array}$ & $\begin{array}{l}\text { Cross, } 143 \text {, social } \\
\text { work, thesis }(0 \text { to } \\
\text { over } 5 \text {, teens to } \\
30 \text { s) }\end{array}$ & $\begin{array}{l}\text { 1) Age } \\
\text { 2) Age of child } \\
\text { 3) Education level } \\
\text { 4) Type of } \\
\text { residence }\end{array}$ & $\begin{array}{l}\text { 5) Child-rearing } \\
\text { attitudes } \\
\text { (PCRAS) } \\
\text { 6) Parental } \\
\text { bonding (PBI) }\end{array}$ & - & $\begin{array}{l}\text { 7) Parent play } \\
\text { beliefs (PPBS) }\end{array}$ & $\begin{array}{l}\text { 8) Parenting } \\
\text { stress (PSI-SF) }\end{array}$ & - & 6 \\
\hline $\begin{array}{l}\text { Park } \\
\text { (2016) }\end{array}$ & $\begin{array}{l}\text { Cross, } 229 \text {, social } \\
\text { work, } \\
\text { dissertation }(0 \text { to } \\
\text { over } 3,16 \sim 50 \text { s })\end{array}$ & $\begin{array}{l}\text { 1) Type of } \\
\text { residence } \\
\text { 2) Age of child }\end{array}$ & $\begin{array}{l}\text { 3) Parenting } \\
\text { confidence } \\
\text { 4) Social network } \\
\text { map (SNM) }\end{array}$ & $\begin{array}{l}\text { 5) Religion } \\
\text { 6) Social support } \\
\text { (SNG) }\end{array}$ & $\begin{array}{l}\text { 7) Self-esteem } \\
\text { (RSES) }\end{array}$ & $\begin{array}{l}\text { 8) Parenting } \\
\text { stress (PSI-SF) } \\
\text { 9) Depression } \\
\text { (DRS) }\end{array}$ & - & 7 \\
\hline $\begin{array}{l}\text { Lee \& } \\
\text { Choi } \\
(2014)\end{array}$ & $\begin{array}{l}\text { Cross, } 122 \text {, child } \\
\text { welfare, journal } \\
\text { (unclear, teens to } \\
\text { over } 30 \text { ) }\end{array}$ & $\begin{array}{l}\text { 1) Cognition of } \\
\text { social } \\
\text { recognition } \\
\text { (CSRS) } \\
\text { 2) Age } \\
\text { 3) Perceived time } \\
\text { about } \\
\text { pregnancy }\end{array}$ & $\begin{array}{l}\text { 4) Cognition of } \\
\text { parental role } \\
\text { (CPRS) }\end{array}$ & $\begin{array}{l}\text { 5) Social support } \\
\text { (SSS) } \\
\text { 6) Experience of } \\
\text { welfare service }\end{array}$ & - & $\begin{array}{l}\text { 7) Loneliness } \\
\text { (RLS-UCLA) }\end{array}$ & $\begin{array}{l}\text { 8) Adoption, } \\
\text { parenting } \\
\text { choice }\end{array}$ & 7 \\
\hline
\end{tabular}

AAS=Adult attachment scale; BDI-II=Beck depression inventory- II; CESD-10=Center of epidemiological studies depression scale revised; Cross=Cross-sectional study; CPRS=Cognition of parental role scale; CSRS=Cognition of social recognition scale; CST=Character strength test; DRS=Depression response scale; DSP=Distress scale for pregnancy; $\mathrm{HPQ}=$ Health perception questionnaire; K-PSI-SF=Korean version-parenting stress index-short form; MSPSS=Multi-dimensional scale of perceived social support; PBI=Parental bonding instrument; PBS=Parenting behavior scale; PCRAS=Parental child-rearing attitudes scale; PMS=Parenting motivation scale; PRSS=Parent role satisfaction scale; PPBS=Parent play beliefs scale; PSI-SF=Parenting stress index-short form; PSOC=Parenting sense of competence; PSS=Perception as a stigma scale; PSY-5 in MMPI-II=Personality psychopathology-five in Minnesota multiphasic personality inventory; RBS=Resiliency belief system; RLS-UCLA=Revised loneliness scale by University of California, Los Angeles; RSES=Rosenberg self-esteem scale; SES=Self-efficacy scale; SNG=Social network grid; SNM=Social network map; SPS=Social prejudice scale; $\mathrm{SSO}=$ Self-sufficiency outcome; SSS=Social support scale; WHOQOL-BREF=Brief form of the World Health Organization quality of life assessment instrument. 
Table 1. Analysis of the Selected Studies (Continued)

\begin{tabular}{|c|c|c|c|c|c|c|c|c|}
\hline $\begin{array}{l}\text { Authors } \\
\text { (year) }\end{array}$ & $\begin{array}{l}\text { Study design, } N \text {, } \\
\text { major field, } \\
\text { publicity (year } \\
\text { age of children } \\
\text { and mothers) }\end{array}$ & Stressors & $\begin{array}{l}\text { Flexible line of } \\
\text { defense/normal } \\
\text { line of defense }\end{array}$ & Line of resistance & Basic structure & Stress responses & Reconstitution & $\begin{array}{c}\text { Quality of } \\
\text { selected } \\
\text { studies }\end{array}$ \\
\hline $\begin{array}{l}\text { Moon \& } \\
\text { Kim } \\
(2014)\end{array}$ & $\begin{array}{l}\text { Cross, } 194 \text {, social } \\
\text { work, journal } \\
(0 \sim 4 \\
16 \text { to over } 25)\end{array}$ & None & $\begin{array}{l}\text { 1) Maternal } \\
\text { parenting } \\
\text { self-efficacy } \\
\text { (PMPS-E) } \\
\text { 2) Parental } \\
\text { bonding (PBI) }\end{array}$ & $\begin{array}{l}\text { 3) Social support } \\
\text { (SSS) }\end{array}$ & - & $\begin{array}{l}\text { 4) Loneliness } \\
\text { (RLS-UCLA) }\end{array}$ & - & 6 \\
\hline $\begin{array}{l}\text { Kim \& } \\
\text { Lee } \\
(2012)\end{array}$ & $\begin{array}{l}\text { Cross, } 65, \text { nursing, } \\
\text { journal }(7 \sim 10, \\
\text { teens to } 39)\end{array}$ & $\begin{array}{l}\text { 1) Age } \\
\text { 2) Education level } \\
\text { of baby's father }\end{array}$ & 3) Usual fatigue & $\begin{array}{l}\text { 4) Social support } \\
\text { (SSS) } \\
\text { 5) Religion }\end{array}$ & $\begin{array}{l}\text { 6) Self-esteem } \\
\text { (RSES) }\end{array}$ & $\begin{array}{l}\text { 7) State trait } \\
\text { anxiety } \\
\text { (STAI-K) }\end{array}$ & - & 8 \\
\hline $\begin{array}{l}\text { Park et al. } \\
\text { (2012) }\end{array}$ & $\begin{array}{l}\text { Cross, } 73 \text {, } \\
\text { medicine, journal } \\
(0,13 \sim 20)\end{array}$ & None & & 1) Disease status & - & - & - & 6 \\
\hline $\begin{array}{l}\text { Cha \& Je } \\
\text { (2010) }\end{array}$ & $\begin{array}{l}\text { Cross, 158, social } \\
\text { work, journal } \\
\text { (unclear, 19 30) }\end{array}$ & 1) Education level & $\begin{array}{l}\text { 2) Family function } \\
\text { (FAD) }\end{array}$ & - & $\begin{array}{l}\text { 3) Differentiation } \\
\text { of self (DOSS) }\end{array}$ & & $\begin{array}{l}\text { 4) Life position } \\
\text { (LPS) }\end{array}$ & 6 \\
\hline $\begin{array}{l}\text { Shin et al. } \\
\text { (2010) }\end{array}$ & $\begin{array}{l}\text { Cross, } 27, \\
\text { medicine, journal } \\
\text { (0 to under } 19)\end{array}$ & None & & 1) Disease status & - & - & - & 6 \\
\hline \multirow[t]{2}{*}{$\begin{array}{l}\text { Jang } \\
\text { (2009) }\end{array}$} & $\begin{array}{l}\text { Cross, } 137 \text {, social } \\
\text { work, thesis ( } 0 \text { to } \\
\text { over } 7 \text {, teens to } \\
40 \text { s) }\end{array}$ & $\begin{array}{l}\text { 1) Age } \\
\text { 2) Age of child } \\
\text { 3) Social prejudice } \\
\text { (SPS) } \\
\text { 4) Type of } \\
\text { residence } \\
\text { 5) Education level }\end{array}$ & - & $\begin{array}{l}\text { 6) Social support } \\
\text { (SSS) }\end{array}$ & - & - & $\begin{array}{l}\text { 7) Parental } \\
\text { satisfaction } \\
\text { (KPSS) } \\
\text { 8) Satisfaction } \\
\text { with life } \\
\text { (SWLS) }\end{array}$ & 7 \\
\hline & & 33 & 17 & 20 & 9 & 12 & 8 & \\
\hline
\end{tabular}

DOSS=Differentiation of self scale; FAD=Family assessment device; KPSS=Kansas parental satisfaction scale; LPS=Life position scale; PBI=Parental bonding instrument; PMPS-E=Perceived maternal parenting self-efficacy; PMS=Parenting motivation scale; RLS-UCLA=Revised loneliness scale by University of California, Los Angeles; RSES=Rosenberg self-esteem scale; SPS=Social prejudice scale; SSS=Social support scale; STAI-K=State-trait anxiety inventory, Korea; SWLS=Satisfaction with life scale.

어 수행하였으며, 3편의 문헌을 대상으로 예비 질 평가(pilot quality assessment)를 시행하여 평가자 간 동일한 기준이 적용될 수 있도록 노력하였다. 예를 들어 신뢰도 평가에서는 Cronbach's $\alpha$ 가 .70 이상을 기준으로 하고, 제시된 하위변수의 신뢰도 값도 .70 이하가 1 개일 때에만 이를 인정하기로 하였다. 구체적인 평가에서 연구자 간 이견이 있는 경우에는 논의를 거쳐 합의를 이루었고, 합 의되지 않는 내용은 간호학 교수 2 인의 자문을 받아 결정하였다 (Table 1).

\section{5. 자료 분석 방법}

일차적으로 선정된 연구의 일반적 특성을 연구 목적, 대상자 특 성, 표본의 크기, 연구 설계 및 측정도구 등으로 파악하였다. 이후 자료 분석 과정은 다음과 같은 단계로 수행하였다.

\section{1) 1 차}

선정된 연구에서 조사한 변수를 모두 확인하였다.

\section{2) 2 차}

본 연구에서 스트레스원은 인간 내적, 대인관계적, 인간 외적 스 트레스원으로 구분하였다. 스트레스원으로 분류한 변수는 각 연 구에서 상관관계와 선형관계를 통해 개별 변수와의 관계를 유의미 한 통계 값으로 제시한 변수로 제한하였다.

\section{3) 3차}

대상자 체계에 속하는 변수를 모아 이를 3개의 방어선, 기본구 조와 반응 및 복구로 분류하였다. 이후, 이 변수를 대상자 체계의 5 가지 변수(생리적, 심리적, 사회문화적, 발달적, 영적 변수)로 재분 류하였다. 이때 분류는 각 연구에서 사용한 측정도구의 특성과 문 항을 평가하여, 그 변수와 NSM개념과의 일치 여부를 판단하여 결 정하였다. 스트레스 반응에 속하는 변수의 분석은 NSM의 근간이 된 스트레스 이론의 내용을 참고하였으며[18], 심리적 특성 변수는 보다 구체적인 정보의 형태로 제공하고자 이를 인지, 정서, 행동, 관계요인으로 세분하였다[19]. 


\section{4) 4 차}

효과크기를 산출하기 위해 본 연구에서는 Comprehensive Meta-Analysis 2.0 프로그램을 사용하여 메타분석을 시행하였다. 메타분석은 독립변수별로 2 편 이상의 연구가 있으며, 분석가능한 정량적 값을 상관계수로 제시한 변수에 한하여 시행하였다.

(1) 자료의 코딩

선정된 15 편의 연구에서 연구 수행 분야, 시기, 설계를 구분하여 자료를 코딩하였다. 더불어 측정도구, 미혼모의 거주형태, 수입 등 을 주요 조절변수로 보고 코딩하였다. 코딩은 1 인의 연구자가 시 행하였으며 제 2 의 연구자가 검토하여 이상치를 발견하면 교정하 였다.

\section{(2) 효과크기 산출}

효과크기 산출근거는 다음과 같다. 1) 분석은 각 연구의 이질성 을 고려하여 가중치를 설정하는 임의효과모형을 사용하였다. 2) 사례 수가 많은 연구에서 제시한 결과값이 더 정확하다고 가정하 여 이에 가중치를 부여하는 가중평균 상관계수 효과크기를 산출하 였다. 3) 동일한 연구에서 보고된 변수가 서로 독립적인 의미를 가 지는 경우에는 개별적으로 제시된 통계치가 서로 다른 특성을 반 영한다고 판단하여 개별 효과크기를 산출하였다. 4) 개별연구에서 하위변수의 효과크기를 분리하여 제시한 경우는 전체 효과크기를 산출하여 분석에 사용하였다. 5) 개별 연구에서 산출된 통계치는 먼저 Fisher Z로 변환한 후 통합하고, 분석된 결과를 다시 상관계 수로 변환하여 제시하였다[20]. 6) 효과크기는 .10보다 작을 경우 '작은 효과크기', .30 수준은 ‘중간 효과크기' , .50 이상은 '큰 효과크 기'로 해석하였다[21]. 7) 출판오류는 funnel plot 및 trim and fill [22] 방법을 이용하여 확인하였다.

\section{5) 5 차}

자료 분석 과정을 통해 파악된 자료와 산출된 효과크기를 이용 하여 미혼모의 스트레스원과 주요 변수 간의 관계를 구조화하였 다. 이 구조화는 NSM에서 제시한 스트레스원 및 3개 방어선의 활 성화에 따른 스트레스 반응에 관한 이론적 명제를 토대로 하였다.

\section{연구 결과}

\section{1. 질 평가 결과}

고찰 대상으로 선정된 논문 15 편은 모두 연구 질문이나 목적을 명확하게 설명하였고, 참여자의 특성을 분명하게 정의하고 있었
다. 13 편에서 표본의 $50 \%$ 이상 대상자가 조사에 참여하였고, 15 편 중 대상자 수를 정한 근거를 제시한 연구는 2편이었다. 15 편 모두 신뢰도와 타당도가 검정된 도구를 사용하여 변수를 측정하였으며, 교란변수를 통계적으로 조절한 연구는 13 편이었다. 이러한 질평 가 결과, 6점이 5편, 7점이 8편, 8점이 2편으로 총 15 편 연구 모두가 6점 이상으로 평가되었다(Table 1) (Appendix 2).

\section{2. 선정된 연구의 일반적 특성}

선정된 15 편의 연구 설계는 모두 서술적 횡단적 조사연구이다. 연구에 참여한 미혼모 수는 총2,077명이었으며, 연구 수행 시기는 2009년에서 2011년이 3편, 2012년에서 2015년이 4편으로, 2016년 에서 2019년 사이에 수행된 연구가 8편이었다. 15편 중 출판된 연 구가 9 편이었으며, 6 편은 학위논문이었다. 연구자의 학문분야는 사회복지학 9편, 간호학 2편, 의학 2편이었고, 심리학과 아동복지 학에서 수행한 연구가 각각 1 편이었다. 참여한 미혼모의 연령은 최 저 13 세에서 최대 50 대였으며, 자녀의 연령은 명확히 밝히지 않은 4편을 제외하고, 영유아에서 12세가량이었다(Table 1).

\section{3. 변수의 분석}

15편의 연구에서 사용한 변수는 총 99 개였다(Tables 1, 2). 이중 미혼모의 스트레스원을 조사한 변수는 33개로 파악되었다(Tables $1,2)$. 유연방어선과 정상방어선에 해당하는 변수는 17 개, 저항선 은 20개, 기본구조는 9개였으며, 스트레스 반응은 12 개, 복구에 해 당하는 변수는 8 개였다. 이를 다시 미혼모 대상자의 5 가지 하위체 계에 속하는 변수로 분류하여, 생리적 변수가 7 개, 심리적 변수가 31 개, 발달적 변수가 22개, 사회문화적 변수가 18개, 영적 변수 6 개, 그리고 기타 NSM의 개념에 속하는 변수가 15 개로 확인되었 다. 이를 미혼모의 스트레스원, 방어선, 대상자 체계의 구조, 스트 레스 반응과 복구 및 미혼모의 스트레스원과 스트레스 반응의 관 계 구조화 순으로 살펴보면 다음과 같다(Tables 1, 2) (Figure 1-B).

\section{1) 스트레스원}

인간 내적 스트레스원으로는 어린 초산 연령, 어린 연령, 임신 중 의 스트레스, 낮은 교육 수준이 확인되었다. 어린 초산 연령은 모아 애착 수준의 저하와 유의미한 관련이 있었으며(Appendix 1. 5), 어린 연령은 낮은 자아존중감(Appendix 1. 11) 및 입양 선택(Appendix 1. 9)과 유의미한 상관을 보여, 미혼모의 어린 연령은 주요 한 스트레스원임을 확인하였다. 또한 미혼모는 학력이 낮을수록 사회적 지지(Appendix 1.4), 구직 효능감(Appendix 1.1), 월 소 
득(Appendix 1. 7)이 낮았으며, 낮은 학력은 사회적 편견에 대한 인식(Appendix 1. 15)과도 유의미한 상관을 보였기에 이를 스트 레스원으로 분류하였다(Tables 1, 2).

대인관계적 스트레스원에는 자녀가 학령 전 아동, 자녀의 건강 문제, 아이 아버지의 낮은 교육 수준이 포함되었다. 특히, 양육 중 인 자녀가 학령 전 연령인 경우에는 미혼모의 애착 수준이 낮고 (Appendix 1.5), 우울감이 높았으며(Appendix 1.4,6), 구직 효능 감이 유의미하게 낮았다(Appendix 1. 1). 또한 아이 아버지의 학 력이 고졸 이하인 것은 미혼모의 낮은 자아존중감과 유의미한 상 관을 보였다(Appendix 1.11) (Tables 1, 2).

인간 외적 스트레스원에는 무직, 적은 수입, 사회적 편견, 기본생 활안전급여 미수급, 거주지 유형(시설, 재가), 불안정한 거주지가 포함되었다. 미혼모가 무직인 경우에는 자녀와의 애착이 낮고(Appendix 1. 5), 양육 스트레스는 높았으며(Appendix 1. 4), 직업이 있는 경우에는 삶의 질이 높은 것으로 보고되었기에(Appendix 1. 6) 미혼모의 무직을 스트레스원으로 분류하였다. 거주지 유형은 상황에 따라 다양한 스트레원으로 작용할 수 있었는데, 재가 미혼 모의 자아존중감은 시설거주 미혼모보다 높은 반면에(Appendix 1. 8), 사회적 망과 복지지원은 시설거주 미혼모에서 유의미하게 높았다(Appendix 1.8). 한편 거주지가 불안정할수록 원가족과의 유대감은 낮은 것으로 나타나(Appendix 1. 7) 불안정한 거주지도 스트레스원에 포함하였다(Tables 1, 2).

\section{2) 대상자 체계의 구조}

(1) 유연방어선과 정상방어선

미혼모의 방어선에 해당하는 생리적 변수는 피로수준(Appendix 1. 11), 건강 수준(Appendix 1.1,6), 건강지각(Appendix 1.4) 이 있었다. 방어선의 기능을 평가하는 변수 중 심리적 변수는 자기 효능감(Appendix 1.3), 원가족과의 유대감(Appendix 1.7,10), 가 족 기능(Appendix 1. 13)이 확인되었고, 사회문화적 변수는 사회 적 망(Appendix 1.8) 변수가 파악되었다. 발달적 변수는 양육 효능 감 관련 변수(Appendix 1.5,8,10), 부모 역할 인지(Appendix 1.9), 양육동기(Appendix 1. 6), 양육행동(Appendix 1. 2), 양육태도 (Appendix 1. 2)가 해당되었으며, 스트레스(Appendix 1. 6)는 신 체적, 심리적, 사회문화적, 발달적 특성을 종합적으로 평가하는 변 수로 확인되었다(Tables 1, 2).

\section{(2) 저항선}

저항선의 침범을 생리적 변수로 확인한 연구는 2편(Appendix 1. 12,14)으로 조산, 양막조기파수, 양수 과소증, 빈혈 등이 이에 해 당된다. 심리적 변수에는 회복탄력성(Appendix 1. 2), 성격 강점
(Appendix 1.6)이 있었는데, 회복탄력성은 인지, 정서, 행동 수준 의 대상자 체계 저항선을 측정할 수 있는 변수라면, 성격 강점은 심 리적 측면뿐만 아니라 영적 측면의 저항선을 함께 평가할 수 있는 복합개념의 변수임을 확인하였다. 또한 저항선에 속하는 변수로 부모의 지지(Appendix 1. 6)와 아이 아버지의 지지(Appendix 1. $5,6)$ 가 파악되었는데, 이는 모두 대인관계적 환경으로부터 오는 심 리적 변수이다. 사회문화적 측면에는 종교(Appendix 1. 8,11)와 복지서비스 이용 경험(Appendix 1.9), 사회적 지지(Appendix 1. 1,3-6,8-11,15)가 포함되었다(Tables 1, 2).

(3) 기본구조

기본구조에 해당되는 심리적 변수에는 자아존중감, 자아분화, 성격의 5 개 요인, 성인애착과 모아애착이 포함되었다. 이 중 자아 존중감(Appendix 1. 1,3,8,11)은 미혼모 자신을 인지적으로 평 가한 변수라면, 자아분화(Appendix 1. 13)와 성격의 5개 요인 (Appendix 1. 6) 변수는 미혼모의 인지, 정서, 행동적 측면을 모두 평가한 복합 개념의 변수였다. 또한 성인애착(Appendix 1. 5)과 모아애착(Appendix 1. 5)은 대인관계적 환경으로부터 오는 변수 로 확인되었다. 한편 발달적 변수에는 놀이 신념(Appendix 1. 7) 이 있었다(Tables 1, 2).

\section{3) 스트레스 반응}

스트레스 반응으로는 정서 수준을 평가하는 불안(Appendix 1. 11), 우울(Appendix 1. 4,5,8)변수가 지속 기간과 강도에 따라 정 상방어선과 저항선의 침범 수준을 확인할 수 있는 변수로 확인되 었다. 외로움(Appendix 1. 9,10)은 관계 측면, 양육 스트레스(Appendix 1. 1,4,5,7,8)는 발달적 측면, 낙인 인식(Appendix 1. 6)은 영적 측면의 스트레스 반응에 해당되었다(Tables 1, 2).

\section{4) 복구}

미혼모의 복구를 평가한 심리적 변수로는 삶의 만족도(Appen$\operatorname{dix}$ 1. 15)와 삶의 위치(Appendix 1. 13)가 확인되었다. 사회문화 적 변수는 자활 성과(Appendix 1. 3), 구직 효능감(Appendix 1. 1), 발달적 변수는 입양/양육의 결정(Appendix 1. 7), 부모 역할 만족도(Appendix 1.6,15)가 확인되었다. 삶의 질(Appendix 1.6) 은 생리적, 심리적, 사회문화적 측면을 모두 평가할 수 있는 변수에 해당되었다(Tables 1, 2).

\section{5) 주요 변수 간 효과크기}

본 연구에서는 메타분석이 가능한 주요 변수의 가중평균 상관계 수 효과크기를 산출하였다. 임의효과모형으로 분석한 결과, 미혼모 
Table 2. Characteristics of Selected Variables

\begin{tabular}{|c|c|c|c|c|c|c|c|}
\hline Variable categories & Stressors & $\begin{array}{l}\text { Flexible line of } \\
\text { defense/normal } \\
\text { line of defense }\end{array}$ & Line of resistance & Basic structure & $\begin{array}{l}\text { Stress } \\
\text { responses }\end{array}$ & Reconstitution & $\begin{array}{c}\text { No of } \\
\text { variables }\end{array}$ \\
\hline I. Physiological & $\begin{array}{l}\text { Health problem } \\
\text { of mother (1), } \\
\text { health problem } \\
\text { of child (1) }\end{array}$ & $\begin{array}{l}\text { Usual fatigue }(1) \text {, } \\
\text { health condition } \\
(2)\end{array}$ & Disease status (2) & & & & 7 \\
\hline 1. Cognitive & & Self-efficacy (1) & & Self-esteem (4) & & $\begin{array}{l}\text { Satisfaction } \\
\text { with life (1), } \\
\text { life position (1) }\end{array}$ & 7 \\
\hline 2. Affective & & & & & $\begin{array}{l}\text { Depression } \\
\text { (3), state-trait } \\
\text { anxiety (1) }\end{array}$ & & 4 \\
\hline $1+2+3$ & & & Resilience (1) & $\begin{array}{l}\text { Differentiation of } \\
\text { self }(1), 5 \text { factors } \\
\text { of personality } \\
\text { psychopathology } \\
\text { (1) }\end{array}$ & & & 3 \\
\hline III. Sociocultural & $\begin{array}{l}\text { Educational level } \\
\text { (6), job (3), grant } \\
\text { support (1), type } \\
\text { of residence (3), } \\
\text { income (1) }\end{array}$ & $\begin{array}{l}\text { Social network } \\
\text { map (1) }\end{array}$ & $\begin{array}{l}\text { Experience of } \\
\text { welfare service } \\
\text { (1) }\end{array}$ & & & $\begin{array}{l}\text { Self-sufficiency } \\
\text { outcome (1), } \\
\text { job search } \\
\text { efficacy (1) }\end{array}$ & 18 \\
\hline V. Spiritual & $\begin{array}{l}\text { Social prejudice } \\
\text { (3) }\end{array}$ & & Religion (2) & & $\begin{array}{l}\text { Perception of } \\
\text { stigma (1) }\end{array}$ & & 6 \\
\hline $\mathrm{I}+\mathrm{II}$ & & $\begin{array}{l}\text { Health perception } \\
\text { (1) }\end{array}$ & & & & & 1 \\
\hline $\mathrm{I}+\mathrm{II}+\mathrm{III}$ & & & & & & $\begin{array}{l}\text { Quality of life } \\
\text { (1) }\end{array}$ & 1 \\
\hline $\mathrm{I}+\mathrm{II}+\mathrm{III}+\mathrm{IV}$ & $\begin{array}{l}\text { Stress during } \\
\text { pregnancy (1) }\end{array}$ & Stress (1) & $\begin{array}{l}\text { Character/ } \\
\text { personality } \\
\text { strength (1) }\end{array}$ & & & & 3 \\
\hline $\mathrm{III}+\mathrm{V}$ & & & $\begin{array}{l}\text { Social support } \\
\text { (10) }\end{array}$ & & & & 10 \\
\hline Total & 33 & 17 & 20 & 9 & 12 & 8 & 99 \\
\hline
\end{tabular}


Table 3. Effect Size Related to Main Variables

\begin{tabular}{|c|c|c|c|c|c|c|c|c|}
\hline Variables & Categories & Related variables & $\mathrm{k}$ & ESr* & SE & $95 \% \mathrm{CI}$ & $\mathrm{Z}(p)$ & $Q^{\S}(p)$ \\
\hline \multirow{5}{*}{$\begin{array}{l}\text { Parenting } \\
\text { stress }\end{array}$} & \multirow[t]{4}{*}{ Protective* } & Self-esteem & 2 & -.64 & 0.06 & $-.78 \sim-.43$ & $-5.18(<.001)$ & $6.92(.009)$ \\
\hline & & $\begin{array}{l}\text { Parenting } \\
\text { self-efficacy }\end{array}$ & 2 & -.54 & 0.01 & $.60 \sim .47$ & $-13.04(<.001)$ & $0.39(.531)$ \\
\hline & & Social support & 3 & -.35 & 0.02 & $-.49 \sim-.20$ & $-6.24(.044)$ & $6.24(.044)$ \\
\hline & & Sub-total & 7 & -.51 & 0.02 & $-.56 \sim-.45$ & $-14.41(<.001)$ & $43.85(<.001)$ \\
\hline & $\operatorname{Risk}^{\dagger}$ & Depression & 3 & .53 & 0.04 & $.36 \sim .66$ & $5.40(<.001)$ & $12.80(.002)$ \\
\hline \multirow{2}{*}{$\begin{array}{l}\text { Parenting } \\
\text { self-efficacy }\end{array}$} & Protective & Social support & 2 & .25 & 0.15 & $.13 \sim .36$ & $5.15(<.001)$ & $1.65(.199)$ \\
\hline & Risk & Depression & 2 & -.45 & 0.01 & $-.51 \sim-.37$ & $-10.43(<.001)$ & $0.43(.514)$ \\
\hline Self-esteem & Protective & Social support & 4 & .37 & 0.09 & $.07 \sim .61$ & $2.40(.017)$ & $46.49(<.001)$ \\
\hline Depression & Protective & Social support & 2 & -.24 & 0.01 & $-.34 \sim-.14$ & $-4.51(<.001)$ & $0.39(.532)$ \\
\hline \multicolumn{3}{|c|}{ Adjusted values of trim and fill } & $\mathrm{k}+$ & $\mathrm{ESr}$ & & $95 \% \mathrm{CI}$ & & Q Value \\
\hline \multirow{2}{*}{\multicolumn{2}{|c|}{$\begin{array}{l}\text { Parenting stress } \\
\text { Protective variables }\end{array}$}} & Observed values & & -.50 & & {$[-.56,-.45]$} & & 1.00 \\
\hline & & Adjusted values & 1 & -.49 & & {$[-.54,-.44]$} & & 1.58 \\
\hline \multirow{2}{*}{\multicolumn{2}{|c|}{$\begin{array}{l}\text { Parenting stress } \\
\text { Risk variables }\end{array}$}} & Observed values & & .53 & & {$[.36, .66]$} & & 12.80 \\
\hline & & Adjusted values & 0 & .53 & & {$[.36, .66]$} & & 12.80 \\
\hline \multirow{2}{*}{\multicolumn{2}{|c|}{$\begin{array}{l}\text { Self-esteem } \\
\quad \text { Protective variables }\end{array}$}} & Observed values & 1 & .37 & & {$[.07, .61]$} & & 46.49 \\
\hline & & Adjusted values & & .42 & & {$[.18, .61]$} & & 53.37 \\
\hline
\end{tabular}

*Mean weighted correlational coefficients; $\dagger$ Variables that correlate with variables negatively; $¥$ Variables that correlate with variables positively; $\S$ Heterogeneity; $\mathrm{CI}=$ Confidence interval; $\mathrm{ESr}=$ Correlational effect size; $\mathrm{k}=$ Objects numbers; $\mathrm{Q}=$ Observed weighted sum of squares.

의 양육 스트레스에 가장 큰 영향을 미치는 변수는 자아존중감으로 효과크기가 -.64 (95\% confidence interval [CI]=-.78 -.43)이어서 매우 큰 상관이 있는 것을 알 수 있었다. 양육 스트레스와 양육 효능 감의 가중평균상관계수 효과크기는 - $.54(95 \% \mathrm{CI}=.60 ~ .47)$ 로 역시 큰 효과크기를 보였다. 우울과 자아존중감의 상관관계는 1 편의 연 구(Appendix 1. 8)에서 보고되었으며, -.66 ( $p$ <.001)로 큰 상관을 보였다. 사회적 지지가 미치는 효과크기는 양육 스트레스에는 -.35 (95\% CI=-.49 -.20), 자아존중감에는 .37 (95\% CI=.07 .61)이었고, 우울에는 -.24 (95\% CI=-.34 -.14)이었다(Table 3).

\section{6) 미혼모의 스트레스원과 스트레스 반응의 관계 구조화}

$\mathrm{NSM}$ 의 개념별로 파악한 주요 변수의 관계를 NSM의 명제를 토대로 하여 다음과 같이 구조화하였다. 우선, 미혼모가 경험하는 스트레스원의 속성을 '상실'과 '부담'으로 명명하였다. 미혼모는 어린 연령에 자녀를 임신하고 출산하면서 학업을 중단하거나 포기 하면서 많은 것을 '상실'할 뿐 아니라, 어머니 역할과 혼자서 자녀 양육을 감당해야 하는 '부담'을 경험한다. 고찰 결과, 미혼모의 '상 실'과 관련 있는 변수는 학업 중단에서부터 원가족 유대감이나 사 회적 편견에 이르기까지 다양하였다. 또한 '부담'은 어린 연령의 출 산, 남편이나 가족의 지원 없는 육아, 이로 인한 신체적·정신적 피
로, 직업이나 소득 상황에 따른 경제적 어려움 등이 해당되는 변수 이다. NSM의 근간이 된 스트레스 이론에 기반하여 분석하였을 때, 미혼모의 정상방어선을 침범할 경우에 나타나는 핵심반응은 인 지 범위의 감소[12,18]로 인한 양육 스트레스임(Appendix 1.1,4,5, $7,8)$ 을 확인하였다. 또한 정상방어선이 침범되었을 때에 미혼모에 게서 나타나는 핵심반응은 우울이었다(Appendix 1. 4,5,8). 이러한 스트레스 반응으로부터 복구를 도울 수 있는 미혼모의 기본구조는 자아존중감으로 드러났다(Appendix 1. 1,3,8,11) (Table 1). 한편, 사회적 지지는 이러한 미혼모의 스트레스 과정에서 미혼모의 양육 스트레스(Appendix 1. 1,4,5,8)와 우울(Appendix 1. 4,5,8)뿐만 아니라 자아존중감(Appendix 1.1,3,8,11)에도 긍정적 변화를 미 치는 변수로 파악되었다. 미혼모의 스트레스를 설명하기 위해 연 구 결과 확인된 변수의 관계를 구조화하여 도식으로 제시하였다 (Figure 1-B).

\section{논 의}

본 연구는 NSM을 이론적 기반으로 미혼모 대상 선행 연구를 통 합적으로 고찰하여 미혼모의 스트레스에 대해 종합적이고 체계적 으로 이해할 수 있는 지식체를 구축하였다. 여기에서는 간호 실무 
와 연구에의 적용가능성에 초점을 두고 미혼모의 스트레스원, 미 혼모 대상자 체계의 방어선과 기본구조 및 이 변수들의 관계를 중 심으로 본 연구 결과를 논의하고자 한다.

스트레스원은 부정적 스트레스 반응을 유발하여 대상자의 건강 수준을 저하시킬 수 있으므로, 스트레스원에 대한 사정은 매우 중 요하다[12]. 본 연구에서는 객관적 측정값을 제시한 연구 결과를 중심으로 관련 선행 연구를 통합적으로 고찰하여 미혼모 사정에 필요한 핵심요인을 제시하였다. 본 연구에서는 미혼모의 스트레 스원에 해당하는 변수 총33개를 NSM의 명제에 근거하여 스트레 스원의 근원이 되는 환경에 따라 인간 내적, 대인관계적, 인간 외적 스트레스원으로 분류하였다. 이 범주화된 스트레스원 자료를 활 용하여 미혼모를 둘러싼 환경을 체계적으로 사정한다면, 미혼모 의 스트레스원을 조기에 예측하고 파악하는 것이 용이할 것이다. 이 결과는 예방적 간호를 위해서는 종합적이고 총체적인 사정이 중요함을 강조한 NSM [12]을 본 연구에 적용하였기에 도출된 것 이다. 또한 본 연구 결과는 스트레스원 분류를 기초자료로 미혼모 의 환경과 스트레스원을 사정할 수 있는 타당도 높은 사정 도구 개 발도 가능할 것이다.

본 연구에서는 미혼모의 스트레스원의 의미를 분석하여 '상실' 과 ‘부담'이라는 두 개의 범주로 분류하였는데, 이는 돌봄제공자의 스트레스원이 책임으로 인한 부담과 돌봄으로 인한 역할 상실이라 는 연구 결과[14]와 유사한 결과이다. 질병을 가진 자녀를 양육하 는 어머니의 주요 스트레스원이 자녀의 질병으로 인한 신체적 불 편감이나 불확실성으로 인한 고립감과 심리적 충격(trauma) [23] 이라는 연구 결과를 통해서 미혼모의 스트레스원은 자녀의 특성이 아닌 어머니의 돌봄제공자 역할에 기인한 것이라고 해석할 있다.

본 연구에서 미혼모의 '상실'로 파악된 변수를 통해서 미혼모를 돕기 위한 정책적 방향을 제시하는 것이 가능하다. 미혼모의 상실 과 관련한 대표적 요인인 학업 중단은 미혼모의 임신을 비정상적 인 성 일탈 행위로 간주하는 사회적 분위기와 남성 중심의 호구제 도의 답습에 기반하고 있다[24]. 그러나 최근 조기 성경험이 꾸준 히 증가하고 있는 현실[25]과 혼인 외 출생아가 차지하는 비율이 증가하고 있는 추이[25]를 반영한다면, 본 연구에서 도출된 미혼모 의 임신과 출산 관련한 상실의 종류를 토대로 하여 이들의 상실 경 험을 최소화하고 기존의 삶을 유지할 수 있도록 도와주는 정책적 지원이 필요하다. 또한 이 연구 결과는 미혼모에 대한 사회적 인식 의 전환과 법 제도의 개선이 필요하다는 주장[26]에 당위성을 부여 하는 구체적인 근거가 될 수 있다.

한편, 미혼모의 부담으로 분류된 스트레스원은 미혼모를 도울 수 있는 사회적인 공공서비스의 요구를 반영하고 있다. 본 연구 결 과 확인된 미혼모의 주된 부담은 남편이나 가족의 지원없이 홀로
육아를 하는 데에서 오는 피로, 자녀 부양에 따르는 경제적 어려움 이었다. 따라서 양육돌봄 서비스와 경제적 지원 마련이 제공된다 면 미혼모의 현실적 욕구가 반영되어 부담 감소에 도움이 될 것이 다. 특히 자녀가 학령전기에 해당되는 경우에 미혼모의 스트레스 가 월등히 높게 분석되었다. 이는 자녀가 36 개월 이상이면 공동거 주시설에서 퇴소해야 하는 한부모지원법 규정이지닌 문제점이 개 선되어야 한다는 주장[26]을 뒷바침해주는 결과이다. 더불어 자율 성과 주도성이 발달하는 학령전기 아동의 특성[27]이 양육의 어려 움으로 작용할 수 있기에 미혼모의 돌봄역량을 강화하기 위한 교 육도 필요할 것이다.

$\mathrm{NSM}$ 의 유연방어선에 해당되는 변수로 미혼모의 피로 수준이 확인되었다. 유연방어선은 스트레스원의 완충효과로써 대상자 체 계를 보호하는 기능을 하므로[12], 미혼모의 스트레스 관리를 위해 서 충분한 휴식이 필요함을 확인할 수 있다. 한편, 정상방어선에는 미혼모의 인지적 수준을 측정할 수 있는 많은 변수가 포함되었다. 스트레스원이 정상방어선을 침범한 경우는 인지 범위가 감소하게 되므로[18], 정상방어선의 기능 수준을 평가하기 위해서는 미혼모 의 인지적 역량을 관찰할 필요가 있다는 것을 확인한 결과이다. 한 편 미혼모의 인지 범위의 축소는 임신에 대한 막연함과 불확실성 으로 인하여 가중되기 쉬운 것으로 보고된 바[28], 정상방어선의 강화를 위한 1 차 예방적 간호중재는 임신, 출산, 육아와 관련한 양 육 지식을 교육하는 중재가 고려될 수 있다.

정상방어선과 저항선의 침범을 확인할 수 있는 주요 변수는 부 정적 정서로 파악되었다. NSM의 명제를 토대로 분석한 결과, 불 안은 정상방어선 침범을 확인할 수 있는 스트레스 반응이며, 우울 은 저항선의 침범으로 인해 나타난 스트레스 반응으로 분석되었 다. NSM에 의하면 정상방어선은 건강한 적응 수준의 기능을 말하 며, 저항선의 침범은 이상상태의 판단기준이 되는 증상을 일으킨 다[12]. 또한 이 방어선의 침범 수준을 파악할 수 있는 대표적인 반 응이 부정적 정서이므로, 이에 대한 사정은 제공해야 할 간호중재 의 수준에 대한 단서와 근거를 제시한다고 설명하고 있다[18]. 그 러므로 미혼모의 불안과 우울은 반드시 사정해야 할 핵심적 요소 가 될 것이다. 예를 들어 경도의 불안을 경험하는 미혼모에게는 정 상방어선을 확장하고 그 기능을 강화시켜 안녕상태를 유지하도록 돕는 1 차 예방적 간호중재 제공이 요구된다. 저항선이 침범되어 기 본구조의 손상이 발생한 경우는 우울과 함께 절망감, 두려움과 공 포 증상을 나타낼 수 있으므로[12,18] 이러한 스트레스 반응을 보 이는 미혼모의 경우에는 급성기 중재를 말하는 2 차 예방과 더불어 체계가 안정상태로 돌아갈 수 있도록 기본구조의 강화를 지원하는 3 차 예방을 제공할 필요가 있다. 기본구조는 대상자 체계의 생명력 의 근원이므로[12] 저항선이 침범되어 총체적인 어려움을 겪는 미 
혼모는 기본구조가 손상되었을 가능성이 높다고 예측할 수 있다. 그러므로 이를 예방하고 손상 시에 효율적인 복구를 위해서는 미혼 모의 기본구조를 사정하고 이를 보호 및 강화하는 것이 중요하다.

본 연구에서는 미혼모의 스트레스를 통합적으로 설명하기 위해 상실과 부담, 양육 스트레스, 우울, 자아존중감 및 사회적 지지의 관계를 구조화하여 도식으로 제시하였다. 이 도식은 자아존중감 이나 자아강도(ego strength)와 같은 기본구조의 특이성에 의해 스트레스원에 대한 반응이 영향을 받는다고 설명한 NSM [12]과 일치되는 관계의 구조를 보여준다. 이 구조화를 위한 본 연구의 메 타분석 결과에서도 자아존중감(기본구조)은 스트레스 반응인 양 육 스트레스 및 우울과 높은 상관을 보이는 것으로 나타나, NSM의 이론적 명제를 뒷받침하였다. 또한 이러한 결과를 통해 미혼모의 복구를 위해서는 기본적인 에너지 자원을 뜻하는 기본구조의 기능 강화에 역점을 두어야 함을 확인하였다. 더불어 이는 자아존중감 이 높은 미혼모의 경우에는 자신의 임신과 출산 선택을 인정하고 존중하므로 우울이 낮다는 연구 결과[29]와 일치한다. 한편 이 도 식화된 관계구조에서 사회적 지지는 저항선에 속하는 핵심변수로 써 방어선을 복구하고 기본구조를 보호할 수 있는 환경적 변수로 작용함을 알 수 있다. 이러한 결과는 자아존중감이 높은 경우 사회 적 지지를 더욱 호의적으로 평가할 뿐 아니라, 적극적으로 도움을 요청한다는 보고[30]를 통해서도 그 관계의 기전을 설명할 수 있 다. 그러므로 미혼모의 기본구조인 자아존중감을 강화하고, 미혼 모의 환경적 변수인 사회적 지지를 확대하는 것이 미혼모의 건강 수준을 향상시키는 간호중재의 초점이 되어야 할 것이다.

본 연구의 결과는 미혼모를 위한 간호 실무에 토대를 마련했을 뿐 아니라 추후 미혼모 관련 연구의 방향을 제시한다는 점에서 그 의의가 있다. 구체적으로, 선정된 변수 중 스트레스원에 대한 각 방 어선의 방어와 복구에는 심리적, 발달적 변수는 많았으나 생리적, 사회문화적, 영적 변수는 상대적으로 적었다. NSM에서 1차 예방 의 초점은 유연방어선과 정상방어선 강화이므로 총체적인 건강증 진을 위해 생리적, 사회문화적, 영적 변수에 대한 추가적 연구가 필 요할 것이다. 또한 근거기반의 중재를 제공하기 위해서는 미혼모 가 경험하는 문제와 건강 수준을 종합적으로 정확히 사정한 후 대 상자의 수준에 따라 1 차, 2 차, 3 차 예방적 중재를 제공하는 것이 바 람직하다. 추후 본 연구 결과를 반영하여 미혼모의 건강 수준을 사 정한 후 수준별 적합한 예방 중재를 고안하여 제공하는 연구를 제 안한다.

본 연구는 미혼모의 스트레스에 관한 질적연구를 포함하지 못 했기 때문에 통합적 고찰이 지닌 방법론적 우수성을 확보하지 못 했다. 또한 본 연구의 고찰 대상이 된 연구가 애초에 NSM에 기반 하여 수행된 연구가 아니라는 점도 본 연구의 제한점이 될 수 있다.
분석 대상인 연구의 이론적 틀이 NSM가 아니었기 때문에, 연구에 서 사용된 변수가 스트레스 반응에 해당되는지 아니면 대상자 체 계의 방어선이나 저항선의 침범 수준을 사정 가능한 변수에 해당 되는지를 명확하게 판단하기 어려운 경우가 있었다. 그러나 통합 적 고찰의 분석 과정에서 경험한 이러한 판단의 어려움은, $\mathrm{NSM}$ 을 이론적 틀로 수행한 선행 연구를 통합적 고찰한 연구[14]에서도 보 고되었다. 이에 Skalski 등[14]은 논의를 통해서NSM의 개념인 스 트레스원은 상황에 따라 대상자 체계를 구성하는 변수로도, 기본 구조에 대한 위험요인으로도 분류될 수 있다고 설명하였다. 이는 $\mathrm{NSM}$ 과 같이 추상성이 높은 간호 모델이 지닌 태생적인 제한점이 기도 하다. 그러므로 본 연구 결과를 연구에 적용할 때에는 대상자 체계로서 미혼모가 스트레스원에 노출되었던 시간과 강도, 그리 고 미혼모가 나타내는 스트레스 반응의 정도를 고려할 것을 제언 한다.

\section{결 론}

본 연구에서는 미혼모를 대상으로 수행된 연구의 변수를 모아 $\mathrm{NSM}$ 을 구성하는 주요 개념인 스트레스원, 방어선, 스트레스 반응, 복구 변수로 분류하여 제시하였다. 또한 미혼모의 스트레스를 설 명하는 핵심적인 변수의 관계를 파악하여 이를 구조화하였다. 그 결과 미혼모의 스트레스원의 속성은 상실과 부담으로 파악되었고, 미혼모의 복구를 돕는 핵심 기본구조는 자아존중감으로 이는 양육 효능감과는 정적 상관을, 양육 스트레스와는 부적 상관을 보였으 며, 사회적 지지와는 정적 상관을 보였다. 따라서 미혼모의 스트레 스원 사정을 위해서는 미혼모의 상실과 부담요인을 파악하는 것이 필요하고, 복구를 위해서는 미혼모의 방어선과 저항선 및 기본구 조의 건강 수준을 파악하여 이에 따라 1 차, 2 차, 3 차 예방 중재를 제 공할 필요가 있다. 본 연구 결과는 미혼모를 위한 사정과 중재 제공 에 활용될 수 있는 기초자료를 제공할 뿐만 아니라, 사회적·정책적 차원의 방향을 안내할 수 있는 근거가 될 수 있을 것이다.

\section{Conflict of interest}

No existing or potential conflict of interest relevant to this article was reported.

\section{REFERENCES}

1. Doh MH, Chae KS. Understanding to women's studies. 1st ed. Paju: Yangseowon; 2008. p. 89-92.

2. Korean Statistical Information Service. Population and housing 
census [Internet]. Daejeon: Korean Statistical Information Service; 2018 [cited 2020 Jan 18]. Available from: https://bit.ly/374TPSx

3. Korean Statistical Information Service. 2018 Birth Statistics [Internet]. Daejeon: Korean Statistical Information Service; 2019 [cited 2020 Mar 29]. Available from: https://bit.ly/2xAAdsA

4. Jeon J, Eom T. A phenomenological study on the experience for unmarried mothers. The Journal of Humanities and Social Science. 2019;10(6):1469-1483. https://doi.org/10.22143/HSS21.10.6.109

5. Oh EJ, Kim HY. Factors influencing unmarried mothers' parenting stress: Based on depression, social support, and health perception. Korean Journal of Women Health Nursing. 2018;24(2):116-125. https://doi.org/10.4069/kjwhn.2018.24.2.116

6. Kwon JM. Experiences of young single mothers' lives through QIMS (Qualitative Interpretive Meta Synthesis). Korean Journal of Qualitative Research in Social Welfare. 2016;10(2):77-103.

7. Park D, Kim H, Kim H, Lee S, Eom J, Kweon O. A study on experiences of child birth and parenting of unmarried single mothers who once were service users of baby box. Journal of Humanities and Social Sciences. 2017;18(4):323-372.

https://doi.org/10.15818/ihss.2017.18.4.323

8. Park IH, So CH, Cho JI, Yu ST, Lee SH, Hong KY, et al. Obstetric and neonatal outcomes of teenage pregnancies. Neonatal Medicine. 2012;19(3):127-133.

https://doi.org/10.5385/jksn.2012.19.3.127

9. Saim NJ, Dufaker M, Eriksson M, Ghazinour M. Listen to the voices of unwed teenage mothers in Malaysian shelter homes: An explorative study. Global Journal of Health Science. 2013;5(5):20-30. https://doi.org/10.5539/gjhs.v5n5p20

10. Lee EJ, Choi KR. The study of related factors affecting unwed mother's decision on self-nurture or adoption of her child. The Korean Journal of Community Living Science. 2014;25(2):247-260. https://doi.org/10.7856/kjcls.2014.25.2.247

11. Ryan RM, Tolani N, Brooks-Gunn J. Relationship trajectories, parenting stress, and unwed mothers' transition to a new baby. Parenting-Science and Practice. 2009;9(1-2):160-177. https://doi.org/10.1080/15295190802656844

12. Neuman B, Fawcett J. The Neuman systems model. 5th ed. Upper Saddle River NJ: Pearson; 2011. p. 1-69.

13. Fawcett J, Desanto-Madeya S. Contemporary nursing knowledge: Analysis and evaluation of nursing models and theories. 3rd ed. Philadelphia PA: F. A. Davis Company; 2013. p. 138-153.

14. Skalski CA, DiGerolamo L, Gigliotti E. Stressors in five client populations: Neuman systems model-based literature review. Journal of Advanced Nursing. 2006;56(1):69-78. https://doi.org/10.1111/j.1365-2648.2006.03981.x

15. Lyttle D, Montgomery AJ, Davis BL, Burns D, McGee ZT, Fogel J. An exploration using the Neuman Systems Model of risky sexual behaviors among African American college students: A brief report. Journal of Cultural Diversity. 2018;25(4):142-147.
16. Whittemore R, Knafl K. The integrative review: Updated methodology. Journal of Advanced Nursing. 2005;52(5):546-553.

https://doi.org/10.1111/j.1365-2648.2005.03621.x

17. National Institute of Health. Quality assessment tool for observational cohort and cross-sectional studies [Internet]. United States of America: National Institute of Health; 2014 [cited 2020 Jan 18]. Available from: https://bit.ly/2WQRkRP.

18. McEwen M. Theoretical basis for nursing. 4th ed. Philadelphia PA: Wolters Kluwer Health/Lippincott Williams and Wilkins; 2014. p. 318-321.

19. Smith MC, ParkerME. Nursing theories and nursing practice. 4th ed. Philadelphia PA: F.A. Davis Company; 2015. p. 170.

20. Borenstein M, Hedges LV, Higgins JT, Rothstein HR. Introduction to meta-analysis. West Sussex HK: John Wiley and Sons Ltd; 2009. p. 1-421.

21. Cohen J. Statistical power analysis for the behavioral sciences. 1st ed. New York: Academic Press; 1969. p. 109-144.

22. Duval S, Tweedie R. Trim and fill: A simple funnel-plot-based method of testing and adjusting for publication bias in meta-analysis. Biometrics. 2000;56(2):455-463.

23. Rechenberg K, Grey M, Sadler L. Stress and posttraumatic stress in mothers of children with type 1 diabetes. Journal of Family Nursing. 2017;23(2)201-225. https://doi.org/10.1177/1074840716687543

24. Kwon HJ. Orphaning babies of unwed mothers in adoption practice. Issues in Feminism. 2015;15(1):51-98. https://doi.org/10.21287/iif.2015.04.15.1.51

25. Korean Statistical Information Service. Juvenile sexual experience [Internet]. Daejeon: Korean Statistical Information Service; 2018 [cited 2020 Jan 18]. Available from: https://bit.ly/2ublZNc

26. Kim JH, Kim HM. Social recognition and legal policy of juvenile unmarried mothers. Korean Academy of Social Welfare and Law. 2018;9(3):109-132.

27. Erikson EH. Childhood and society. 2nd ed. New York NY: Norton; 1963. p. 1- 445.

28. Kim HS, Lee MH. Relationship among perceived self-esteem, social support, and state anxiety in community-dwelling unmarried mother raising a child. The Journal Of the Korea Contents Association. 2012;12(11):225-235.

https://doi.org/10.5392/JKCA.2012.12.11.225

29. Park YH. Study on the differences of the government social support for unmarried mother child-rearing between at the home and in the facilities. The Journal of the Korea Contents Association. 2016;16(1):493-502. https://doi.org/10.5392/JKCA.2016.16.01.493

30 . Oh SH. The relationship among self-esteem, self-efficacy and selfsufficiency outcomes of unmarried mother discharged from the welfare facilities: Focusing on mediating effect of social support from welfare facilities [master's thesis]. Busan: Pukyong National University; 2018. p. 1-84. 


\section{Appendix 1. Citations for Studies Included in This Study}

1. Chang SA. A study of factors that influence the job-seeking efficacy of child-rearing unwed mothers [master's thesis]. Seoul: Soongsil University; 2018. p. 1-110.

2. Kim YM, Lee HM. Influence of resilience on positive parenting behavior in young single mothers: The mediating effects of social prejudice. The Journal of The Korea Contents Association. 2018;18 (7):153-164. https://doi.org/10.5392/JKCA.2018.18.07.153

3. Oh SH. The relationship among self-esteem, self-efficacy and selfsufficiency outcomes of unmarried mother discharged from the welfare facilities: Focusing on mediating effect of social support from welfare facilities [master's thesis]. Busan: Pukyong National University; 2018. p. 1-84.

4. Oh EJ, Kim HY. Factors influencing unmarried mothers' parenting stress: Based on depression, social support, and health perception. Korean Journal of Women Health Nursing. 2018;24(2):116-125. https://doi.org/10.4069/kjwhn.2018.24.2.116

5. Kim SR. Factors influencing the attachment of the unmarried mothers to their children [master's thesis]. Daejeon: Chungnam National University; 2017. p. 1-100.

6. Park YA, Lee YH. Quality of life of unmarried mothers: A study of character strengths. Korean Journal of Woman Psychology. 2017; 22(2):143-171. https://doi.org/10.18205/kpa.2017.22.2.003

7. Jung E. A study on unmarried mother's emotional distress that comes from raising her child alone [master's thesis]. Seoul: Sookmyung Women's University; 2016. p. 1-71.

8. Park YH. A study of the factors influencing child-rearing efficacy of unmarried mothers [dissertation]. Yongin: Kangnam University; 2016. p. 1-149.
9. Lee EJ, Choi KR. The study of related factors affecting unwed mother's decision on self-nurture or adoption of her child. The Korean Journal of Community Living Science. 2014;25(2):247-260. https://doi.org/10.7856/kjcls.2014.25.2.247

10. Moon JS, Kim YH. The effects of emotional connection with parents, social support, and isolation on unmarried mothers' childrearing efficacy. Journal of Korean Home Management Association. 2014;32(6):109-123.

https://doi.org/10.7466/JKHMA.2014.32.6.109

11. Kim HS, Lee MH. Relationship among perceived self-esteem, social support, and state anxiety in community-dwelling unmarried mother raising a child. The Journal of The Korea Contents Association. 2012;12(11):225-235. https://doi.org/10.5392/JKCA.2012.12.11.225

12. Park IH, So CH, Cho JI, Yu ST, Lee SH, Hong KY, et al. Obstetric and neonatal outcomes of teenage pregnancies. Neonatal Medicine. 2012;19(3):127-133.

https://doi.org/10.5385/jksn.2012.19.3.127

13. Cha MJ, Je SB. A study on family function, self differentiation, and life position of unmarried mothers and college students. Korean Journal of Family Social Work. 2010;29:175-198.

14. Shin JH. Obstetric and neonatal outcomes of the teenage pregnancy [master's thesis]. Seoul: Korea University; 2011. p. 1-23.

15. Jang HJ. Study on factors that affect the life satisfaction of unmarried mothers: With a focus on parent satisfaction, social support and social prejudice [master's thesis]. Seoul: Soongsil University; 2009. p. 1-86. 


\section{Appendix 2. Quality Assessment of Selected Studies}

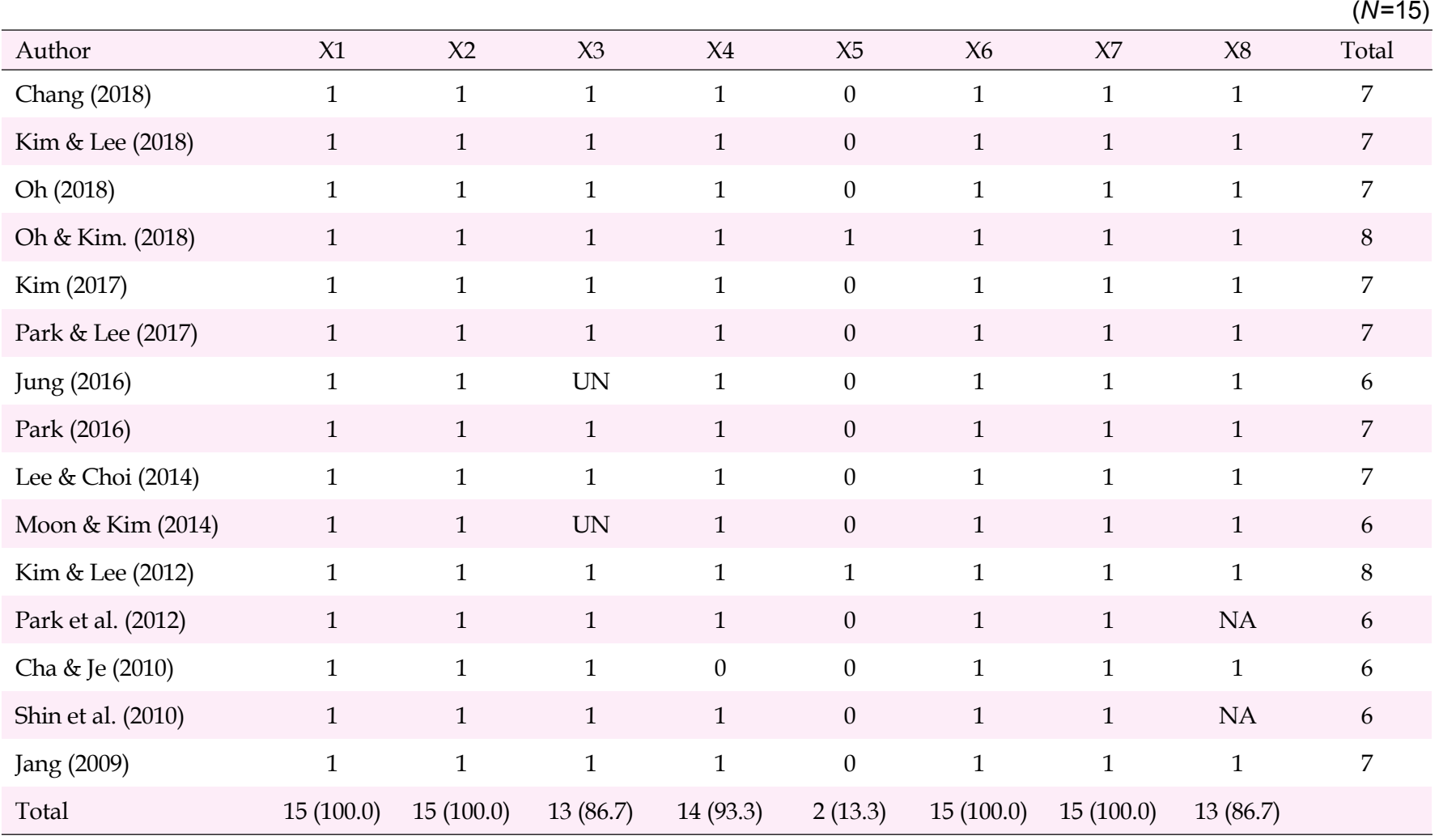

NA=Not applicable; $U N=$ Unclear; $X 1=$ Research question clearly stated?; $X 2=$ Study population clearly defined; $X 3=$ Response rate $>50 \% ; X 4=A l l$ the subjects recruited from the similar population?; $X 5=$ Appropriate/ justified sample size; $X 6=$ Were the exposure measures clearly defined?; $X 7=W e r e$ the outcome measures clearly defined; $\mathrm{X} 8=$ Confounding variables measured and adjusted statistically. 